\title{
KERJA SAMA OTORITAS PAJAK DAN OTORITAS ANTI KORUPSI DALAM UPAYA MENINGKATKAN KEPATUHAN PAJAK
}

\author{
Redhy Matabean ${ }^{a}$, Vishnu Juwono ${ }^{b}$ \\ a Direktorat Jenderal Pajak, Indonesia. Email: redhy.matabean@ui.ac.id \\ b Direktorat Jenderal Pajak, Indonesia.Email: vjuwono@ui.ac.id
}

\begin{abstract}
Tax crimes and corruption have caused huge losses in various countries. Therefore, one of the emphases of the Sustainable Development Goals is how to reduce corruption substantially in all its forms. Corruption and tax crimes can be interrelated. Hence, appropriate policies are needed from the tax authorities and anti-corruption authorities in handling them. This study aims to discover the collaboration design in dealing with tax crimes and corruption. The analysis results illustrate that systematic design can be carried out through collaboration between tax authorities and anti-corruption authorities by considering three aspects. The first aspect is identifying tax non-compliance behaviour, the second is identifying tax crime and corruption indicators, while the third aspect is determining the form of collaboration needed. This study also opens up opportunities for collaboration in the form of information exchange by the Directorate General of Taxes and the Corruption Eradication Commission through a tax monitoring and public complaints database and state administrators' assets report.
\end{abstract}

Keywords: Tax Policy, Tax Crime, Corruption, Collaboration, Information Exchange

\section{ABSTRAK}

Kejahatan pajak dan korupsi telah menimbulkan dampak kerugian yang sangat besar di berbagai negara. Oleh sebab itu salah satu fokus dari Sustainable Development Goals adalah bagaimana mengurangi korupsi secara substansial dalam semua bentuknya. Korupsi dan kejahatan pajak dapat saling berkaitan oleh karena itu diperlukan kebijakan yang tepat dari otoritas pajak dan otoritas anti korupsi dalam menanganinya. Studi ini bertujuan untuk mengetahui desain kerjasama yang dapat dilakukan dalam menangani kejahatan pajak dan korupsi. Hasil analisis memberikan gambaran bahwa desain sistematis dapat dilakukan melalui kerja sama antar otoritas pajak dan otoritas anti korupsi dengan mempertimbangkan tiga aspek. Aspek pertama adalah mengidentifikasi perilaku ketidakpatuhan pajak, aspek kedua adalah mengidentifikasi indikator kejahatan pajak dan korupsi, sedangkan aspek ketiga adalah menentukan 
bentuk kerja sama yang diperlukan. Studi ini juga membuka peluang kerjasama berupa pertukaran informasi oleh Direktorat Jenderal Pajak dan Komisi Pemberantasan Korupsi melalui sistem informasi pengawasan pajak dan basis data pengaduan masyarakat serta pelaporan harta penyelenggara negara.

Kata kunci: Kebijakan Pajak, Kejahatan Pajak, Korupsi, Kerja sama, Pertukaran Informasi

\section{PENDAHULUAN}

Pajak dan korupsi dapat saling terkait karena pelaku korupsi akan kesulitan melaporkan pendapatan yang diperoleh dari kegiatan korupsi untuk pelaporan pajaknya. Berdasarkan data Bank Dunia atas 25.000 perusahaan di 57 negara ditemukan data bahwa perusahaan yang lebih banyak melakukan suap cenderung juga lebih banyak menghindari pajak (World Bank Policy Research Working Paper dalam OECD, 2018). Dalam perspektif yang lebih luas, di mana praktik korupsi telah menjadi kelaziman di masyarakat maka kondisi ini dapat mendorong terjadinya tax evasion (OECD, 2018). Sebuah survei perusahaan Intelligence Fusion Centre (IFC) menemukan bahwa 13,3\% bisnis secara global melaporkan kondisi dimana "perusahaan diharapkan memberikan hadiah dalam pertemuan dengan pejabat pajak", dengan frekuensi dari nol hingga 62,6\% (OECD, 2018).

Isu korupsi telah menimbulkan kerugian dan dampak yang luas pada berbagai sektor. Persatuan Bangsa Bangsa (PBB) mencatat bahwa setiap tahunnya sekitar $\$ 2,6$ triliun hilang akibat korupsi. Nilai tersebut setara dengan 5\% dari Pendapatan Domestik Bruto (PDB) secara global. Korupsi juga telah menyebabkan sekitar $\$ 50$ miliar raib setiap tahunnya di kawasan Afrika. Bahkan perusahaan multinasional seperti Goodyear asal Amerika Serikat menyuap pejabat Kenya dan Angola sekitar \$3,2 juta untuk memenangkan kontrak (Irfan, 2017).

Nilai kerugian negara akibat korupsi di Indonesia juga menunjukkan angka yang signifikan. Berdasarkan data dari Indonesia Corruption Watch (ICW), sepanjang 2017 terdapat 576 kasus korupsi dengan kerugian negara mencapai Rp6,5 triliun dan suap Rp211 miliar (Saputri, 2018). Adapun kerugian negara dalam kurun waktu 2001-2005 berdasarkan hasil kajian Laboratorium IImu Ekonomi Universitas Gadjah Mada mencapai Rp203,9 triliun.

Sementara hukuman denda dan sita aset hanya terkumpul sebesar Rp21,26 triliun sehingga rakyat harus mensubsidi sebesar Rp182,64 triliun. Kerugian negara tersebut melibatkan 2.321 kasus dan 3.109 terdakwa. Hasil kajian tersebut juga menunjukkan bahwa hukuman finansial terhadap terpidana korupsi cenderung suboptimal, lebih rendah dibandingkan dengan kerugian negara yang diakibatkan (Mohammad, 2016).

Dalam laporan Transparency International, Indonesia menempati peringkat 89 dari 180 negara dengan skor 38 pada Corruption Perception Index (CPI) atau Indeks Persepsi Korupsi pada tahun 2018 (Transparancy International, 2019). Laode M Syarif, selaku pimpinan Komisi Pemberantasan Korupsi (KPK), menyatakan bahwa Indeks Persepsi Korupsi (IPK) ditentukan oleh berbagai komponen seperti layanan publik, kepastian hukum, kemudahan 
berbisnis, dan relasi antara politik dengan bisnis. Perbaikan sejumlah parameter itu tak hanya menjadi tugas KPK saja sebagai otoritas anti korupsi di Indonesia, tapi juga seluruh pemangku kepentingan di Indonesia. Laode menegaskan bahwa upaya KPK untuk menaikkan skor IPK akan sulit dicapai tanpa dukungan pihak lain. Sebanyak apa pun upaya penindakan yang dilakukan KPK dalam upaya pemberantasan korupsi, tidak akan cukup tanpa upaya bersama berbagai elemen bangsa (KPK, 2018).

KPK telah berusaha melakukan perbaikan sistem sebagai upaya pencegahan dan pemberantasan korupsi. Salah satunya dengan melibatkan peran masyarakat untuk memberikan informasi dan pengaduan adanya indikasi tindak pidana korupsi. Berdasarkan data yang diambil dari situs KPK, terdapat 6.000 pengaduan pada tahun 2017 yang meningkat pada tahun 2018 menjadi 6.468 laporan dugaan korupsi berbagai entitas, baik orang pribadi maupun korporasi (KPK, 2019).

Walaupun masih harus melalui proses verifikasi untuk dapat dikategorikan sebagai laporan yang dapat ditindaklanjuti oleh KPK, data tersebut dapat menjadi early warning bagi kepentingan otoritas lain yang berkepentingan termasuk diantaranya otoritas pajak terkait pengawasan kewajiban perpajakan dari entitas yang dilaporkan.

Aliran keuangan gelap (illicit financial flow) ditengarai sebagai salah satu penyebab hilangnya potensi penerimaan negara dari praktik penghindaran pajak. Penelitian dari Perkumpulan Prakarsa pada tahun 2019 menyebutkan bahwa dalam kurun waktu 1989 - 2017, aliran keuangan gelap dari enam komoditas ekspor unggulan berupa batu bara, minyak sawit, tembaga, karet, kopi dan udang-udangan mencapai $\$ 142,07$ miliar. Penelitian tersebut juga mengungkapkan bahwa sebanyak \$101,40 miliar merupakan aliran keuangan gelap yang masuk ke Indonesia dengan skema over invoicing. Sementara aliran keuangan gelap yang keluar dari Indonesia dengan cara under invoicing mencapai $\$ 40,58$ miliar (Kartika, et al., 2019). Bentuk ini dapat dikategorikan tax evasion karena ada unsur kesengajaan dalam manipulasi data bahkan dapat termasuk tax fraud atau kejahatan pajak ketika terjadi aktivitas melanggar hukum dalam aliran keuangan gelap tersebut.

Pada tahun 2015, Perserikatan Bangsa-Bangsa telah menyetujui 17 Sustainable Development Goals (SDGs), termasuk target khusus untuk mengurangi korupsi secara substansial dalam semua bentuknya. Dalam konteks ini, OECD dan Bank Dunia mendukung setiap yurisdiksi untuk memperkuat kerangka hukum dan kelembagaan mereka untuk pencegahan, deteksi, investigasi, penuntutan, dan pengembalian hasil kejahatan kejahatan pajak dan korupsi. Pada tahun 2012, Satuan Tugas Aksi Keuangan (FATF) sebuah organisasi antar pemerintah yang didirikan pada tahun 1989 atas prakarsa the Group of Seven (G7) untuk memberantas pencucian uang memasukkan korupsi, penyuapan, dan kejahatan pajak dalam daftar pelanggaran sebagai bentuk pencucian uang dalam Standar Internasional tentang Pemberantasan Pencucian Uang dan Pendanaan Terorisme dan Proliferasi. 
Otoritas pajak dan otoritas anti korupsi dapat melakukan kerja sama sistematis untuk mengatasi kejahatan pajak dan korupsi. Otoritas pajak memiliki data kekayaan pribadi dan perusahaan serta informasi seperti pendapatan, aset, transaksi keuangan, dan informasi perbankan yang dapat menjadi sumber informasi berharga bagi otoritas antikorupsi. Sebaliknya, otoritas anti korupsi dapat memberikan informasi penting tentang investigasi korupsi yang dapat membantu keputusan untuk membuka kembali audit pajak atau investigasi atas kejahatan di bidang perpajakan. Namun demikian pada beberapa negara, pelaporan dan pembagian informasi antara pihak berwenang sering terjadi secara ad-hoc. Hal ini diperkuat oleh studi OECD pada tahun 2017 yang menyatakan bahwa hanya 2\% dari kasus penyuapan yang terselesaikan antara 1999 dan 2017 yang terdeteksi oleh otoritas pajak (OECD, 2018).

Contoh keberhasillan peningkatan kerja sama antara otoritas pajak dan otoritas penegak hukum terkait korupsi adalah kasus investigasi terhadap perusahaan minyak milik Brazil, Petrobras, yang dimulai pada tahun 2014. Auditor pajak berperan penting dalam investigasi korupsi transnasional dengan menganalisis data pajak dan bea cukai dari tersangka dan berbagi informasi dengan penegak hukum Brazil. Hasil kerja sama tersebut adalah terungkapnya bukti pencucian uang, penghindaran pajak, dan penyembunyian aset serta pelacakan arus keuangan. Kerja sama tersebut juga menyeret banyak pejabat publik dan politisi serta miliaran dolar denda pidana, denda pajak, dan pengembalian aset (OECD, 2018).

Pemerintah telah menerbitkan Peraturan Presiden Republik Indonesia Nomor 54 tahun 2018 tentang Strategi Nasional Pencegahan Korupsi. Perpres ini menekankan upaya strategis yang perlu dilakukan untuk mencegah korupsi, mendorong program pencegahan korupsi yang menghasilkan hasil dan dampak yang terukur, dan meningkatkan sinergi antara program pencegahan korupsi dengan kebijakan pemerintah serta kebijakan strategis dari Komisi Pemberantasan Korupsi (KPK). Sebagai bagian dari implementasi kebijakan tersebut, maka sinergitas otoritas pajak dan KPK perlu ditingkatkan untuk mendukung agenda pemberantasan korupsi dan optimalisasi penerimaan negara.

Menurut OECD (2018), masih ada ruang yang signifikan untuk peningkatan kerja sama antara otoritas pajak dan otoritas anti korupsi. Dalam laporan OECD (2018) setidaknya ada 53 negara telah menerapkan kerja sama antar otoritas secara sistematis pada praktik internasional. Oleh karena itu, Peraturan Presiden Nomor 54 tahun 2018 telah membuka ruang kajian bagaimana kerja sama sistematis antara otoritas pajak dan otoritas anti korupsi yang dapat diimplementasikan di Indonesia berdasarkan rekomendasi OECD sebagaimana juga telah diterapkan pada berbagai negara.

Berpijak dari hal tersebut, penulis tertarik untuk membahas bagaimana desain dan peluang kerja sama antar otoritas dalam menangani kejahatan pajak dan korupsi untuk meningkatkan kepatuhan pajak sesuai rekomendasi OECD. Penelitian ini menggunakan pendekatan 
kualitatif dengan jenis penelitian deskriptif. Penelitian ini juga diharapkan dapat menjadi sumbangan pemikiran bagi pengambil kebijakan pada otoritas terkait dalam mensukseskan agenda pemberantasan korupsi sekaligus meningkatkan kepatuhan pajak.

Berdasarkan hal tersebut maka penelitian ini bertujuan untuk:

1. Menganalisis bagaimana desain kerja sama otoritas pajak dan otoritas anti korupsi dalam menangani kejahatan pajak dan korupsi.

2. Menganalisis peluang kerja sama Direktorat Jenderal Pajak dan Komisi Pemberantasan Korupsi dalam menangani kejahatan pajak dan korupsi sebagai upaya meningkatkan kepatuhan pajak.

\section{TINJAUAN PUSTAKA}

Menurut OECD (2017a), setiap yurisdiksi memiliki definisi berbeda terkait terminologi kejahatan pajak atau tax crime. Namun secara umum, OECD menyatakan bahwa tax crime adalah "intentional conduct that violates a tax law, and is intended to be broad enough to accommodate the different legal definitions that may apply under domestic law. It is intended to cover the violation of both tax law obligations, as well as indirect tax obligations (such as VAT or GST)". Beberapa yurisdiksi juga dapat memberikan batasan berbeda pada jenis tax crime berupa non compliance offences, intentional tax offences dan specific offences (OECD, 2017a).
Kejahatan pajak berkaitan dengan kesengajaan dalam melakukan perbuatan yang bertentangan dengan undang-undang dengan maksud memperoleh keuntungan yang berakibat pada kerugian negara. Adyan (2007) menyatakan bahwa kejahatan pajak termasuk kejahatan yang sulit dijangkau oleh hukum (offences beyond the reach of the law). Hal ini disebabkan oleh pelaku yang profesional, periode kejahatan yang cukup lama, dan keterkaitan dengan sektor lain seperti pemerintah, swasta dan masyarakat.

Salah satu referensi definisi untuk korupsi adalah semua pelanggaran yang diatur dalam Bab III Konvensi Perserikatan Bangsa-Bangsa Melawan Korupsi (UNCAC), termasuk penyuapan pejabat publik baik domestik maupun asing di sektor publik ataupun swasta, penggelapan, penyalahgunaan properti, perdagangan pengaruh, penyalahgunaan fungsi, dan pengayaan illegal (OECD, 2018). Adapun definisi korupsi menurut Transparency International adalah "the abuse of entrusted power for private gain" (https://www.transparency.org).

Adapun perbuatan korupsi dalam Pasal 2 Undang-Undang Nomor 31 Tahun 1999 jo. UU Nomor 20 Tahun 2001 tentang Pemberantasan Tindak Pidana Korupsi didefinisikan sebagai "Setiap orang yang secara melawan hukum melakukan perbuatan memperkaya diri sendiri atau orang lain atau suatu korporasi yang dapat merugikan keuangan negara atau perekonomian negara...". Dalam Pasal 3, korupsi dinyatakan sebagai "Setiap orang yang dengan tujuan menguntungkan diri sendiri atau orang lain atau suatu korporasi, menyalahgunakan kewenangan, kesempatan atau sarana yang ada 
padanya karena jabatan atau kedudukan yang dapat merugikan keuangan negara atau perekonomian negara ..."

Terdapat beragam definisi dari konsep tax evasion dan tax fraud. Konsep tax evasion menurut (Boháč, 2015) sebagaimana dikutip oleh Saxunova et al. (2017) dapat dipahami sebagai situasi di mana pajak tidak ditetapkan sesuai aturan hukum sedangkan konsep tax fraud didefinisikan sebagai kejahatan penipuan (crime of fraud) dari perspektif hukum pidana. Adapun The European Commission (EC-Taxation and Customs Union, 2017) dalam Saxunova et al. (2017) mendefinisikan perbedaan terminologi Tax Fraud, Tax Evasion dan Tax Avoidance sebagai berikut:

1) Tax Fraud - "adalah bentuk penghindaran pajak yang disengaja yang dapat ditindak di bawah hukum kriminal. Istilah ini mencakup situasi di mana pernyataan palsu yang sengaja diajukan atau dokumen palsu yang diproduksi"

2) Tax Evasion - "umumnya terdiri dari pengaturan ilegal di mana kewajiban pajak disembunyikan atau diabaikan, yaitu pembayar pajak membayar pajak lebih sedikit dari yang seharusnya dibayar berdasarkan undang-undang dengan menyembunyikan pendapatan

3) Tax Avoidance - "didefinisikan sebagai tindakan sesuai hukum untuk meminimalkan atau menghilangkan pajak yang seharusnya secara hukum terutang. Seringkali melibatkan eksploitasi dokumen hukum yang ketat, celah dan ketidakcocokan untuk mendapatkan keuntungan pajak yang awalnya tidak dimaksudkan oleh undang-undang ".

Konsep kepatuhan pajak menurut Langham, et al. (2012) dipengaruhi oleh yaitu kesempatan secara legal dan niatan. Dua faktor tersebut menjadi kombinasi penyebab dari munculnya isu ketidakpatuhan pajak. Kesempatan secara legal berarti bahwa sesuatu yang dilakukan Wajib Pajak tidak menyalahi ketentuan secara ketentuan perundang-undangan.

Adapun niatan dapat diartikan sebagai perilaku atau nilai yang diyakini kebenarannya di masyarakat. Keyakinan ini menjadi timbul karena hal yang sama dilakukan oleh orang-orang di sekitarnya tanpa diimbangi tindakan tegas dari otoritas pajak.

Penelitian terdahulu oleh Yustinus Prastowo (2017) menyebutkan bahwa performa penerimaan pajak yang rendah disebabkan oleh rendahnya kapasitas dalam enforcement serta tingkat kepercayaan yang rendah akibat tingginya tingkat korupsi. Untuk mengintegrasikan agenda pemberantasan korupsi dan peningkatan kepatuhan pajak diperlukan desain baru atas struktur koordinasi antara institusi pemerintah.

Adapun Bernd Schlenther (2017) dalam penelitiannya membahas berbagai instrumen mitigasi dalam upaya pencegahan korupsi dan penghindaran pajak. Schlenther juga menyatakan bahwa aspek penting yang perlu dilakukan otoritas pajak adalah meningkatkan transparansi dan akuntabilitas, perlindungan terhadap whistle blower, dan peningkatan leadership dalam pelayanan kepada publik. 


\section{PEMBAHASAN}

\subsection{Desain Kerja sama Otoritas Pajak dan Otoritas Anti Korupsi}

Penanganan kejahatan pajak dan korupsi di Indonesia saat ini dilakukan oleh otoritas yang berbeda. Dengan tantangan yang semakin meningkat maka diperlukan kerja sama antar otoritas melalui strategi yang tepat agar tindakan yang dilakukan berjalan efektif.

Berdasarkan rekomendasi OECD, desain kerja sama antara otoritas pajak dan otoritas anti korupsi perlu mempertimbangkan tiga aspek penting yaitu (i) mengidentifikasi perilaku ketidakpatuhan pajak, (ii) mengidentifikasi indikator kejahatan pajak dan indikator korupsi, dan (iii) menentukan bentuk kerja sama antar otoritas (OECD 2017a, 2018).

1) Mengidentifikasi perilaku ketidakpatuhan pajak.

Isu ketidakpatuhan pajak memicu terjadinya penghindaran pajak hingga kejahatan pajak. Pelaku ketidakpatuhan pajak akan selalu mencari cara baru dan melakukan berbagai upaya baik legal maupun ilegal untuk menghindari pajak. (Saxunova, et al., 2017). Ketidakpatuhan pajak menurut Langham, et al. (2012) disebabkan oleh adanya kesempatan secara legal serta adanya niatan dari pelaku. Kesempatan secara legal ini dapat berwujud celah aturan hukum sehingga menjadi 'pembenaran' suatu tindakan yang dilakukan oleh pelaku karena merasa tidak menyalahi aturan tersebut. Sebagai solusi, Langham, et al (2012) menyarankan kepada otoritas pajak agar memahami kelemahan pada aturan yang berlaku dan mengaplikasikan perbaikan sistem sehingga bisa menginter- vensi persepsi masyarakat untuk meningkatkan kepatuhan. Dalam konteks ini, maka peningkatan mekanisme kerja sama antar otoritas menjadi bagian dari perbaikan sistem pengawasan kepada wajib pajak.

OECD telah menerbitkan 10 Prinsip Global untuk Memerangi Kejahatan Pajak pada tahun 2017. Sepuluh prinsip tersebut dapat menjadi panduan untuk melakukan kajian atas aturan domestik dalam mendesain kebijakan menangani kejahatan pajak dan mengidentifikasi di area mana perbaikan dapat dilakukan. Dalam desain kebijakan tersebut diperlukan strategi yang efektif sebagaimana prinsip ke-2 rekomendasi OECD "Devise an Effective Strategy for Addressing Tax Crimes". Otoritas pajak perlu melakukan identifikasi berbagai variasi ketidakpatuhan pajak dan strategi spesifik dalam menangani setiap bentuk ketidakpatuhan tersebut (OECD, 2017b).

Dalam panduan strategi mengatasi ketidakpatuhan pajak pada Gambar. 1, OECD (2017b) membagi tindakan ketidakpatuhan pajak menjadi empat kategori yaitu Tax Compliance, Tax Avoidance, Tax Evasion, dan Tax Fraud. Masing-masing kategori tersebut diatasi dengan metode berbeda sesuai dengan tingkat ketidakpatuhannya. Untuk tingkat ketidakpatuhan berupa Tax Compliance diperlukan strategi simplifikasi pelayanan. Tax Avoidance diatasi dengan fokus pada pengawasan dan kerja sama, sedangkan untuk Tax Evasion yang diperlukan adalah kontrol dan sanksi atas wajib pajak. Adapun untuk Tax Fraud diperlukan strategi lebih serius dalam melawan dan mencegah (combatting and preventing) fraud berupa investigasi dan audit pajak, tuntutan dan hukuman, eliminasi dari legal financial circles serta kerja 
sama dengan sistem peradilan dan kepolisian.

Perilaku ketidakpatuhan wajib pajak yang telah dipetakan tersebut dapat menjadi landasan bagaimana bentuk penanganan selanjutnya. OECD (2004) telah merekomendasikan penggunaaan Compliance Risk Management (CRM) dalam memahami perilaku ketidakpatuhan pajak dan bagaimana strategi yang tepat dalam menanganinya.
Dalam disertasinya, Pratomo (2018) menyebutkan urgensi penggunaan CRM sebagai tata kelola kepatuhan, sehingga program CRM telah masuk dalam peta strategi Direktorat Jenderal Pajak tahun 2015-2019. Namun sampai saat ini penggunaan CRM oleh DJP masih dalam tahap piloting sebagaimana dipaparkan dalam tesis Andiko (2018).

Gambar 1.

Bentuk Tindakan Ketidakpatuhan Pajak dan Rekomendasi Strategi Penangannya

\begin{tabular}{|c|c|c|c|}
\hline $\begin{array}{r}\text { Tax fraud } \\
\text { (serious organised crime) }\end{array}$ & $\begin{array}{l}\text { Combatting and } \\
\text { preventing fraud }\end{array}$ & \multirow{3}{*}{ 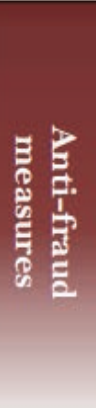 } & $\begin{array}{l}\text { - } \quad \text { Tax investigation and audits } \\
\text { - } \quad \text { Prosecution and penalties } \\
\text { - } \quad \text { Cooperation with the judicial system/police }\end{array}$ \\
\hline $\begin{array}{r}\text { Tax evasion } \\
\text { (shadow economy, } \\
\text { income underreporting, } \\
\text { illegal employment) }\end{array}$ & $\begin{array}{l}\text { Controls and } \\
\text { sanctions }\end{array}$ & & $\begin{array}{l}\text { - Controls, investigations } \\
\text { - Tax audits (risk analysis) } \\
\text { - Prosecution and penalties } \\
\quad \text { Tax collection }\end{array}$ \\
\hline $\begin{array}{r}\text { Tax avoidance } \\
\text { (aggressive tax planning, } \\
\text { avoidance models) }\end{array}$ & $\begin{array}{l}\text { Monitoring and } \\
\text { cooperation }\end{array}$ & & $\begin{array}{l}\text { - } \quad \text { Risk management } \\
\text { - Office and field staff controls } \\
\text { - } \quad \text { Official first visits } \\
\text { Tax collection }\end{array}$ \\
\hline $\begin{array}{r}\text { Tax compliance } \\
\text { (voluntary disclosure, } \\
\text { fulfilment of tax obligations) }\end{array}$ & $\begin{array}{l}\text { Support an } \\
\text { simplification }\end{array}$ & & $\begin{array}{l}\text { - Information and forms } \\
\text { - } \quad \text { Horizontal monitoring } \\
\text { - Advance rulings }\end{array}$ \\
\hline
\end{tabular}

Sumber: OECD, 2017b

2) Mengidentifikasi Indikator Kejahatan Pajak dan Korupsi

Setelah mengidentifikasi perilaku ketidakpatuhan dan melakukan penanganan melalui CRM, maka hal yang penting dilakukan adalah bagaimana mengidentifikasi indikator kejahatan pajak dan indikator korupsi. Hal ini sejalan dengan pendapat Andiko (2018) bahwa pemanfaatan CRM tidak akan optimal apabila tidak didukung data yang memadai. Oleh sebab itu dalam pengembangan CRM sebagai manajemen kepatuhan, data indikator kejahatan pajak dan korupsi dapat dimasukkan sebagai variabel pengawasan kepada wajib pajak dengan kriteria tertentu.

Secara umum indikator dari suap dan korupsi dapat dilihat dari aspek Affirmative Indications dan Affirmative Acts. Aspek Affirmative Indications berhubungan dengan gaya hidup yang tidak sesuai dengan profil penghasilan, transaksi bisnis dengan laba tidak wajar, dan hubungan tidak wajar antara wajib pajak dan konsultan eksternal. Sementara itu, aspek 
Affirmative Acts berkaitan dengan penghapusan catatan keuangan, penyembunyian rekening bank dan transaksinya, serta penyembunyian sumber atau tujuan pembayaran (OECD, 2018).

Dalam hal ini, aspek yang perlu diperhatikan dalam desain kebijakan kerja sama antar otoritas adalah bagaimana pemahaman otoritas pajak terhadap indikator korupsi dan sebaliknya bagaimana pemahaman otoritas anti korupsi terhadap tax crime. OECD (2018) telah merekomendasikan indikator korupsi apa saja yang harus dipahami baik oleh otoritas pajak maupun otoritas anti korupsi dalam kerangka kerja sama ini sebagaimana Tabel 1 berikut:

Tabel 1. Indikator Korupsi Dan Tax Crime Yang Perlu Diidentifikasi oleh Otoritas Pajak dan Otoritas Anti Korupsi

\begin{tabular}{|c|c|c|}
\hline Kriteria & $\begin{array}{c}\text { Identifikasi Indikator } \\
\text { Korupsi oleh Otoritas } \\
\text { Pajak }\end{array}$ & $\begin{array}{l}\text { Identifikasi Indikator Tax } \\
\text { Crime } \\
\text { oleh Otoritas Anti Korupsi }\end{array}$ \\
\hline $\begin{array}{l}\text { External risk } \\
\text { environment }\end{array}$ & $\begin{array}{l}\text { Entitas yang beroperasi di } \\
\text { negara atau industri berisiko } \\
\text { korupsi tinggi dan } \\
\text { beroperasi di sektor dengan } \\
\text { regulasi tinggi. }\end{array}$ & $\begin{array}{l}\text { Industri dengan resiko komersial } \\
\text { tinggi atau wajib pajak dengan } \\
\text { tekanan keuangan, sektor } \\
\text { dengan pajak yang tinggi, celah } \\
\text { yang dieksploitasi untuk } \\
\text { penghindaran membayar pajak. }\end{array}$ \\
\hline $\begin{array}{l}\text { Internal risk } \\
\text { environment }\end{array}$ & $\begin{array}{l}\text { Struktur hukum atau } \\
\text { hubungan yang dapat } \\
\text { dieksploitasi untuk tujuan } \\
\text { korupsi, perusahaan dengan } \\
\text { internal kontrol yang lemah, } \\
\text { sejarah tindakan korupsi. }\end{array}$ & $\begin{array}{l}\text { Struktur hukum yang } \\
\text { memfasilitasi tax crime, metode } \\
\text { bisnis yang dapat } \\
\text { menyembunyikan penghasilan } \\
\text { atau memfasilitasi tax crime, } \\
\text { sejarah adanya tax evasion atau } \\
\text { tax crime. }\end{array}$ \\
\hline Transactions & $\begin{array}{l}\text { Transaksi tidak wajar yang } \\
\text { tidak sesuai aktivitas bisnis, } \\
\text { melibatkan pihak yang } \\
\text { mencurigakan }\end{array}$ & $\begin{array}{l}\text { Pembayaran suap kepada } \\
\text { pejabat domestik atau asing, } \\
\text { pembayaran mencurigakan } \\
\text { kepada pejabat publik, aset yang } \\
\text { belum diumumkan kepada } \\
\text { otoritas pajak, rekening asing } \\
\text { atau tersembunyi }\end{array}$ \\
\hline $\begin{array}{l}\text { Payments and } \\
\text { money flows }\end{array}$ & $\begin{array}{l}\text { Pembayaran yang tidak jelas } \\
\text { sumber dan tujuannya dan } \\
\text { mencurigakan }\end{array}$ & - \\
\hline $\begin{array}{l}\text { Outcomes of } \\
\text { transactions }\end{array}$ & $\begin{array}{l}\text { Transaksi dengan hasil yang } \\
\text { tidak berhubungan dengan } \\
\text { aktivitas bisnis, catatan dan } \\
\text { aset keuangan tidak wajar }\end{array}$ & $\begin{array}{l}\text { Perusahaan yang mengalami } \\
\text { kerugian permanen, hasil yang } \\
\text { tidak wajar, catatan tidak } \\
\text { lengkap/dirusak }\end{array}$ \\
\hline Receiving a bribe & $\begin{array}{l}\text { Menerima suap atau hasil } \\
\text { korupsi }\end{array}$ & $\begin{array}{l}\text { Menerima pembayaran yang } \\
\text { terindikasi korup }\end{array}$ \\
\hline
\end{tabular}


Menurut OECD (2018), peningkatan kemampuan identifikasi atas indikator kejahatan pajak dan korupsi ini perlu dilakukan oleh masing-masing otoritas. Kelemahan sistem pengawasan yang terjadi dapat direduksi melalui pemahaman yang lebih baik terkait aktivitas dan lingkungan bisnis atas entitas yang masuk kategori high risk. Kesadaran atau awareness atas indikator tax crime atau korupsi akan memudahkan otoritas tersebut dalam mengidentifikasi suatu transaksi yang mencurigakan dan dapat menjadi informasi berharga bagi otoritas lain yang berkepentingan melalui pertukaran informasi. Pratomo (2018) menyatakan bahwa ketidakmampuan otoritas pajak Indonesia dalam mendeteksi ketidakpatuhan pajak disebabkan oleh keterbatasan informasi dan tidak efektifnya mekanisme pertukaran informasi antar otoritas.

3) Menentukan Bentuk Kerja sama Antar Otoritas Dalam Menangani Tax Crime dan Korupsi

OECD dan Bank Dunia pada tahun 2018 telah merekomendasikan tahapan dalam kerangka kerja sama antar otoritas pajak dan otoritas anti korupsi. Tahapan pertama adalah melakukan identifikasi peran dan hubungan serta kewenangan masing-masing otoritas dan bagaimana interaksi antar otoritas saat ini. Langkah selanjutnya adalah mempertimbangkan bentuk yang lebih efektif dan tantangan dalam melakukan kerja sama baik dari aspek legal, hambatan operasional, dukungan kultur, dan politik yang sangat mungkin terjadi. Apakah misalnya terdapat peluang pertukaran informasi dan investigasi bersama.

Langkah berikutnya terkait mekanisme kerja sama. Misalnya dalam kerja sama pertukaran serta pelaporan dan pembagian informasi, apakah akan bersifat terbatas, diskresi (pilihan) atau wajib. Bentuk ideal yang disarankan oleh OECD (2018) adalah dalam bentuk well-managed mandatory. Dalam kerja sama antar otoritas juga diperlukan pelatihan atas indikator tax crime dan korupsi bagi petugas otoritas. Selain itu bentuk operasi bersama, data intelijen, serta penugasan staf antar otoritas disarankan agar dapat meningkatkan enforcement capacity bagi masing-masing otoritas.

Setelah menetapkan tahapan kerja sama antar otoritas, selanjutnya diperlukan penentuan bentuk kerja sama yang dibutuhkan dalam menangani tax crime dan korupsi. Kerja sama otoritas pajak dan otoritas anti korupsi dapat dilakukan dengan kerangka sebagaimana rekomendasi OECD (2018) dalam delapan area. Area tersebut berupa Threat assessment, Detection, Referral, Information sharing, Join investigations and sharing capability, Strengthened enforcement outcomes, Institutional integrity, dan Policy development. Fungsi dari masing-masing otoritas sesuai kapasitas dan kewenangan yang telah diatur dalam aturan perundang-undangan, dapat ditingkatkan dalam bentuk kerja sama. Adapun kerja sama antar otoritas pajak dan otoritas anti korupsi dapat dijabarkan sebagaimana Tabel 2. di bawah ini. 
Tabel 2

Bentuk Kerja Sama Otoritas Pajak dan Otoritas Anti Korupsi Berdasarkan Rekomendasi OECD

\begin{tabular}{|l|l|}
\hline $\begin{array}{c}\text { Bentuk Kerja } \\
\text { Sama }\end{array}$ & \multicolumn{1}{|c|}{ Keterangan } \\
\hline $\begin{array}{l}\text { Threat } \\
\text { assessment }\end{array}$ & $\begin{array}{l}\text { Otoritas pajak mengidentifikasi individu dalam suatu organisasi (baik } \\
\text { di pemerintahan maupun sektor privat yang terindikasi korupsi, } \\
\text { sebaliknya otoritas anti korupsi menyediakan tipe profil yang } \\
\text { beresiko terlibat korupsi }\end{array}$ \\
\hline Detection & $\begin{array}{l}\text { Otoritas pajak mendeteksi indikator korupsi dimana penghasilannya } \\
\text { tidak sesuai dengan gaya hidup, sebaliknya otoritas anti korupsi } \\
\text { dapat mendeteksi indikator dari tax crime berupa aset atau } \\
\text { penghasilan yang berusaha disembunyikan atau korupsi yang } \\
\text { melibatkan pejabat publik }\end{array}$ \\
\hline $\begin{array}{l}\text { Referral } \\
\text { Information } \\
\text { sharing }\end{array}$ & $\begin{array}{l}\text { Masing-masing otoritas dapat menyerahkan kecurigaan tax crime } \\
\text { atau korupsi untuk investigasi dan penegakan hukum lebih lanjut }\end{array}$ \\
\hline $\begin{array}{l}\text { Masing-masing otoritas dapat berbagi informasi dan data yang } \\
\text { diperoleh dari investigasi berupa penghasilan, aset, transaksi } \\
\text { finansial, informasi perbankan termasuk informasi yang melibatkan } \\
\text { yurisdiksi luar negeri }\end{array}$ \\
\hline $\begin{array}{l}\text { Jinvestigations } \\
\text { and sharing } \\
\text { capability }\end{array}$ & $\begin{array}{l}\text { Masing-masing otoritas dapat bekerja sama dalam investigasi dan } \\
\text { penegakan hukum misalnya dalam hal analisis terhadap subjek dan } \\
\text { potensi korupsi atas temuan audit dan investigasi pajak. }\end{array}$ \\
\hline $\begin{array}{l}\text { Strengthened } \\
\text { enforcement } \\
\text { outcomes }\end{array}$ & $\begin{array}{l}\text { Masing-masing otoritas dapat saling melengkapi celah/kelemahan } \\
\text { aturan dengan kerja sama penegakan hukum sehingga tuntutan atas } \\
\text { perilaku tax crime dan korupsi dapat maksimal. }\end{array}$ \\
\hline $\begin{array}{l}\text { Institutional } \\
\text { integrity }\end{array}$ & $\begin{array}{l}\text { Tindakan preventif terjadinya potensi tax crime yang melibatkan } \\
\text { pejabat publik atau oknum petugas masing-masing otoritas melalui } \\
\text { kerja sama pencegahan }\end{array}$ \\
\hline $\begin{array}{l}\text { Policy } \\
\text { development }\end{array}$ & $\begin{array}{l}\text { Masing-masing otoritas dapat terlibat dalam mengembangkan } \\
\text { kebijakan mengatasi kejahatan ekonomi }\end{array}$ \\
\hline
\end{tabular}

Sumber: OECD, 2018, Diolah Oleh Penulis

OECD (2018) menyatakan bahwa salah satu bentuk kerja sama dalam bentuk joint investigations and sharing capability dilakukan dalam Operasi X di Australia. Operasi ini adalah investigasi bersama banyak lembaga terhadap dugaan penipuan sistemik atas GST. Investigasi bersama tersebut diformalkan dalam suatu perjanjian dan diawasi oleh Komite Manajemen Gabungan, yang terdiri dari Koordinator Kepolisian Australia (AFP) untuk Operasi Kejahatan dan Direktur Nasional dari Departemen Perpajakan Australia (ATO). 
Petugas ATO dikirim ke AFP untuk memberikan dukungan investigasi yang sedang berlangsung dan memfasilitasi pengungkapan informasi yang dilindungi ATO, termasuk data pembayar pajak, analisis atas data dan informasi yang relevan dengan Fraud Prevention and Internal Investigations (FPII). AFP menyita lebih dari 1,5 juta AUD dari tiga individu terkait dengan Operasi $X$. Ketiga orang ini berhasil dituntut atas uang yang dicurigai sebagai hasil kejahatan. Investigasi gabungan ini juga menghasilkan penuntutan yang sukses terhadap mantan staf ATO yang terlibat.

Contoh bentuk kerja sama lain adalah penerapan di Georgia, dimana kasus korupsi terdeteksi melalui assessment atas dugaan kejahatan pajak (OECD, 2018). Pada tahun 2014, dilakukan investigasi terhadap perusahaan yang diduga melakukan kejahatan perpajakan dengan penggunaan dokumen palsu. Investigator otoritas pajak menilai kembali kewajiban pajak perusahaan dan ditemukan fakta bahwa terjadi rekayasa pengeluaran dari suatu proyek negara, dan melakukan fraud atas dokumen penghasilan kena pajak mereka. Georgia mencatat bahwa pejabat negara terindikasi korupsi karena terlibat dalam kontrak dengan perusahaan, dan bertanggung jawab atas kasus tersebut.

Kerja sama antar otoritas pajak dan otoritas anti korupsi tersebut akan meningkatkan kinerja masing-masing otoritas. Menurut penelitian Prastowo (2017) kerja sama DJP dan institusi lain akan menciptakan sistem pengawasan dan pemantauan yang lebih baik sebagai upaya penegakan hukum atas korupsi. Lebih lanjut dijelaskan oleh Prastowo bahwa kerja sama tersebut juga diharapkan dapat membangun basis data yang komprehensif dalam upaya memaksimalkan potensi pajak. Oleh karena itu, DJP diharapkan dapat mengambil peran dalam kerja sama antar otoritas dengan memilih bentuk paling efektif dalam upaya meningkatkan kepatuhan pajak dengan segala kondisi dan keterbatasan yang ada.

\subsection{Peluang Kerja sama antara DJP dan KPK}

Kebijakan pajak adalah kebijakan fiskal dalam arti sempit (Mansury,1999). Termasuk didalamnya adalah kebijakan penentuan basis pajak, subjek pajak, objek pajak, pengecualian serta bagaimana menentukan prosedur pelaksanaan kewajiban oleh wajib pajak. Dalam konteks tersebut maka kerja sama otoritas pajak dengan otoritas lain sebagai upaya menangani tax crime untuk meningkatkan penerimaan pajak adalah bagian dari instrumen kebijakan pajak. Salah satu bentuk kebijakan pajak yang memiliki peran penting dalam kerja sama tersebut adalah pertukaran informasi atau information sharing.

Bentuk kerja sama information sharing menjadi penting karena menurut Prastowo (2017), kerja sama DJP dan otoritas lain dalam membangun basis data pajak yang komprehensif akan menjadi tools efektif dalam memaksimalkan hak negara dari penerimaan pajak. Data dari pihak ketiga tersebut akan memiliki peran yang sangat penting untuk mencegah dan mengantisipasi penghindaran pajak yang agresif, pengelakan pajak serta menangani kejahatan pajak. Di sisi lain otoritas anti korupsi seperti KPK mendapatkan 
feeding data indikasi korupsi yang membantu upaya pencegahan korupsi.

Peran KPK dalam melaksanakan pemberantasan korupsi di sektor perpajakan sejatinya dapat dilakukan melalui pencegahan. Menurut Pasal 1 ayat 3 Undang-Undang Nomor 30 tahun 2002, pemberantasan korupsi adalah "serangkaian tindakan untuk mencegah dan memberantas korupsi melalui upaya koordinasi, pengawasan, pemantauan, investigasi, penuntutan dan pemeriksaan di pengadilan, dengan partisipasi dari peraturan berbasis masyarakat. Dalam konteks perpajakan, maka "pemberantasan" termasuk pencegahan korupsi yang berasal dari kejahatan pajak. Oleh sebab itu kerja sama pertukaran informasi relevan dengan konteks pencegahan korupsi tersebut.

Direktorat Jenderal Pajak (DJP) dan Komisi Pemberantasan Korupsi (KPK) dapat melakukan kerja sama berupa information sharing. Masing-masing otoritas tersebut dapat berbagi informasi dan data berupa penghasilan, aset, transaksi finansial, informasi perbankan termasuk informasi yang melibatkan yurisdiksi luar negeri. DJP memiliki kapasitas dan kewenangan untuk melakukan pengawasan terhadap wajib pajak. Sementara KPK memiliki basis data pelaporan indikasi korupsi berdasarkan laporan masyarakat serta Laporan Harta Kekayaan Penyelenggara Negara (LHKPN) dari penyelenggara negara.

Salah satu kewenangan DJP adalah melakukan pengawasan kepada wajib pajak. Pengawasan wajib pajak merupakan serangkaian kegiatan penelitian data hingga tindak lanjut pengawasan dalam rangka penggalian potensi perpajakan, pengawasan kepatuhan pemenuhan kewajiban perpajakan pengawasan kepatuhan pemenuhan kewajiban perpajakan wajib pajak, dan peningkatan penerimaan perpajakan sesuai dengan ketentuan peraturan perundang-undangan di bidang perpajakan.

Kegiatan pengawasan wajib pajak oleh DJP saat ini dilakukan melalui sistem informasi bernama Approweb sebagai tools yang merupakan aplikasi penyandingan data internal dan data eksternal dalam melakukan pengawasan. Pada tahun 2015 dilakukan pengembangan terhadap Aplikasi Approweb dengan berlakunya SE-10/PJ/2015 tentang Pedoman Administrasi Pembangunan, Pemanfaatan dan Pengawasan Data (PAP3D). Pada Approweb Generasi Ketiga ini terdapat setidaknya tiga tools pengawasan yang dapat dioptimalkan dalam upaya kerja sama antar otoritas. Pertama, Modul Profil Wajib Pajak yang terdiri atas data dan informasi dari setiap wajib pajak yang dikumpulkan dari berbagai sumber baik internal DJP maupun dari pihak ketiga. Kedua, Modul Data dan Analisis yang merupakan modul untuk mendeteksi secara dini ketidakpatuhan wajib pajak dengan memunculkan kasus-kasus tertentu. Ketiga, Modul Aktivitas Pengawasan sebagai modul khusus untuk pengawasan terhadap wajib pajak.

Pada sisi lain KPK memiliki basis data pelaporan publik atas indikasi dugaan korupsi serta data kekayaan penyelenggara negara. Ketika menemukan indikasi tindakan korupsi, publik dapat mengunjungi website KPK lalu pilih menu "KPK Whistleblower's System", atau 
langsung mengaksesnya melalui: http://kws.kpk.go.id. Indikasi tindakan korupsi tersebut antara lain berupa perbuatan melawan hukum memperkaya diri orang/badan yang merugikan keuangan/perekonomian negara, menyalahgunakan kewenangan karena jabatan/kedudukan yang dapat merugikan keuangan/perekonomian negara, penggelapan dalam jabatan, pemerasan dalam jabatan, serta tindak pidana yang berkaitan dengan pemborongan dan delik gratifikasi. KPK saat ini juga diberikan kewenangan mengadministrasikan Laporan Harta Kekayaan Penyelenggara Negara (LHKPN) dari penyelenggara negara. Laporan Harta Kekayaan Penyelenggara Negara menggunakan aplikasi yang berbasis web dengan alamat elhkpn.kpk.go.id, sehingga data yang dilaporkan Penyelenggara Negara secara otomatis tersimpan dalam server yang ada di KPK. Data e-LHKPN berisi Data Pribadi, Jabatan, Keluarga, Harta, Penerimaan, Pengeluaran, dan Penerimaan Fasilitas.

Kerja sama pertukaran informasi dan pengawasan indikator korupsi dan tax crime antara DJP dengan KPK dapat memanfaatkan Approweb dan data e-LHKPN serta KPK Whistleblower's System. Modul Aktivitas Pengawasan, Modul Data dan Analisis dan Modul Profil Wajib Pajak pada Approweb dalam kegiatan pengawasan wajib pajak dapat dimanfaatkan untuk mendeteksi indikator fraud yang berpotensi korupsi sehingga menjadi feedback bagi KPK untuk tindakan selanjutnya.

Sebaliknya, basis data KPK yang telah diverifikasi dan memunculkan indikator tax crime dapat menjadi sumber data potensial bagi DJP untuk ditindaklanjuti sesuai ketentuan. Dalam praktiknya tentu saja kerja sama sistematis ini membutuhkan perangkat aturan sebagai payung hukum agar konstruksi kerja sama tersebut dapat terwujud.

Bentuk kerja sama information sharing antara Direktorat Jenderal Pajak dan Komisi Pemberantasan Korupsi tersebut dapat digambarkan melalui skema pada Gambar. 2. Modul pengawasan wajib pajak pada Approweb dan basis data KPK dimanfaatkan sebagai jembatan pertukaran informasi antar otoritas dari indikator kejahatan pajak dan korupsi yang muncul dari suatu entitas. Sebagaimana rekomendasi tahapan ke-4 OECD bahwa bentuk ideal dari mekanisme pelaporan dan pembagian informasi adalah bersifat well-managed mandatory.

Desain kerja sama sistematis antara otoritas pajak dengan otoritas lain pada hakikatnya bertujuan meningkatkan kepatuhan pajak. Direktorat Jenderal Pajak memerlukan dukungan informasi dari berbagai pihak, tidak terkecuali otoritas anti korupsi seperti KPK dalam mengawasi kepatuhan pajak. Apabila indikasi kejahatan pajak dapat dimitigasi sejak awal maka diharapkan upaya memaksimalkan potensi penerimaan negara dapat berjalan efektif dan lebih efisien karena didukung oleh data yang relevan dan reliable. 
Gambar 2. Skema Kerja Sama Pertukaran Informasi DJP-KPK

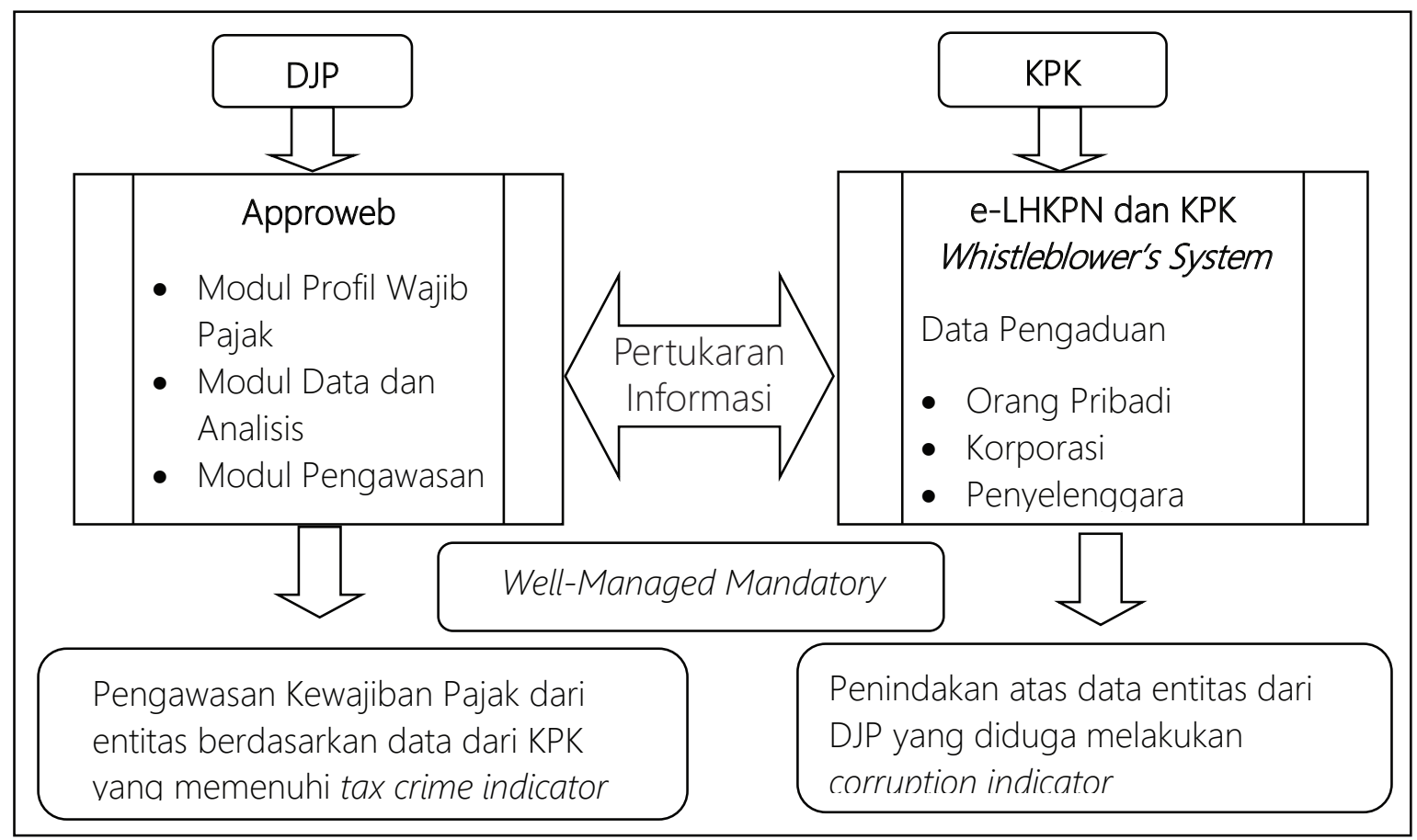

Sumber: Diolah Oleh Penulis

Desain kerja sama sistematis antara otoritas pajak dengan otoritas lain pada hakikatnya bertujuan meningkatkan kepatuhan pajak. Direktorat Jenderal Pajak memerlukan dukungan informasi dari berbagai pihak, tidak terkecuali otoritas anti korupsi seperti KPK dalam mengawasi kepatuhan pajak. Apabila indikasi kejahatan pajak dapat dimitigasi sejak awal maka diharapkan upaya memaksimalkan potensi penerimaan negara dapat berjalan efektif dan lebih efisien karena didukung oleh data yang relevan dan reliable. Di sisi lain, adanya kerja sama pengawasan melibatkan KPK dengan berbagai sumber daya yang belum dimiliki oleh DJP diharapkan dapat mencegah munculnya tindakan kejahatan pajak. Hal ini tentunya sangat mendukung upaya DJP dalam meningkatkan kepatuhan pajak.

\section{KESIMPULAN}

Desain kebijakan kerja sama secara sistematis antar otoritas pajak dan otoritas anti korupsi perlu mempertimbangkan tiga aspek penting yaitu bagaimana mengidentifikasi perilaku ketidakpatuhan pajak, bagaimana melakukan identifikasi indikator tax crime dan korupsi oleh masing-masing otoritas, serta bagaimana memilih bentuk kerja sama yang dilakukan. Terdapat peluang kerja sama sistematis dengan bentuk information sharing antara DJP dan KPK dengan mekanisme pelaporan dan pembagian informasi yang bersifat well-managed mandatory dengan memanfaatkan Aplikasi Approweb, e-LHKPN, serta KPK Whistleblower's System. 
Apabila kerja sama pertukaran informasi antar otoritas dapat terlaksana, DJP dapat memperoleh data entitas dari KPK atas indikator tax crime untuk diawasi kewajiban perpajakannya sekaligus memberikan feedback berupa profil ketidakpatuhan pajak atas entitas yang memenuhi indikator korupsi kepada KPK. Kerja sama ini diharapkan dapat menjadi salah satu strategi yang mendukung upaya meningkatkan kepatuhan pajak.

\section{DAFTAR PUSTAKA}

[1] Adyan, A. (2007). Penegakan hukum Pidana terhadap Tindak Pidana di Bidang Perpajakan. Jurnal Pranata Hukum, 2(2). Diakses dari http://jurnal.ubl.ac.id/index.php/PH/article/view/107

[2] Andiko, T. (2018). Analisis Implementasi Kebijakan Pemeriksaan Pajak di Indonesia Ditinjau Dari Konsep Cooperative Compliance (Master Thesis). Universitas Indonesia.

[3] Langham, Jo'Anne \& Paulsen, Neil \& Hartel, Charmine. (2012). Improving tax compliance strategies: Can the theory of planned behaviour predict business compliance? eJournal of Tax Research. 10. 345-363. Diakses dari https://www.researchgate.net/publication/236147172_Improving tax_compliance_strategies_Can_the_theo$r y \_o f \ldots p l a n n e^{-} d_{-} b e-$ haviour_predict_business_compliance.

[4] Mansury, R. (1999). Kebijakan Fiskal, Jakarta: YP4.

[5] OECD. (2004). Compliance Risk Management: Managing and Improving Tax Compliance. Paris: Forum on Tax Administration. Diakses dari https://www.oecd.org/tax/administration/33818656.pdf

OECD. (2017), Effective Inter-Agency Co-op-

[6] eration in Fighting Tax Crimes and Other Financial Crimes - Third Edition, Paris: OECD Publishing. Diakses dari http://www.oecd.org/tax/crime/effective-inter-agen$c y$ - c o - o p e r a tion-in-fighting-tax-crimes-andother-financi al-crimes.htm
[8] OECD (2017), Fighting Tax Crime: The Ten Global Principles, Paris: OECD Publishing.

Diakses dari http://www.oecd.org/tax/crime/fighting-tax-crime-the-ten-global-principles.htm

[9] OECD. (2018). Improving Co-operation between Tax Authorities and Anti-Corruption Authorities in Combating Tax Crime and Corruption. Paris: OECD and the World Bank. Diakses dari http://www.oecd.org/tax/crime/i m proving - co-operation-be tween-tax-authorities-and-anti-corruption-a uthorities-in-combating-tax-crime-and-corru ption.htm

[10] Prastowo, Y. (2017). New Perspective of Comprehensive Reform: Integrating Corruption Eradication and Tax Optimization Agenda. In Tax and Corruption Symposium. Sydney. Diakses dari https://www.business.unsw.edu.au/About-Site/Schools-Site/Taxation-Business-Law-Site/Documents/Wednesd ay_PM_Yustinus_Prastowov.pdf

[11] Pratomo, M. (2018). Investigating Tax Compliance Risks of Large Businesses in Indonesia (Ph.D Dissertation). RMIT University. Diakses dari https://researchbank.rmit.edu.au/eserv/rmit:162418/Pratomo.pdf

[12] Saxunova, D., Sulikova, R., \& Szarkova, R. (2017). Tax Management Hierarchy - Tax Fraud and a Fraudster. In Management International Conference. Monastier di Treviso (Venice). Diakses dari http://www.hippocampus.si/ISBN/978-961-7023-71-8/236.pdf

[13] Schlenther, B. (2017). The impact of corruption on tax revenues, tax compliance and economic development: Prevailing trends and mitigation actions in Africa. Ejournal Of Tax Research, 15(2), 217-242. Diakses dari http://www5.austlii.edu.au/au/journals/eJlTaxR/2017/11.html

[14] Republik Indonesia. 2001. Undang-Undang Nomor 20 Tahun 2001 tentang Perubahan atas Undang-Undang Nomor 31 Tahun 1999 tentang Pemberantasan Tindak Pidana Korupsi. Jakarta

[15] Republik Indonesia. 2002. Undang-Undang Nomor 30 Tahun 2002 tentang Komisi Pemberantasan Tindak Pidana Korupsi. Jakarta 
[16] https://www.transparency.org. Diakses 8 September 2019 dari https://www.transparency.org/whoweare/organisation/faqs_on_corruption/2\#defineCorruption

[17] Irfan, M. (2017, 9 Desember). Catatan Buruk Korupsi di Dunia. Diakses 20 Desember 2018 dari https://tirto.id/catatan-buruk-korupsi-di-dunia-cBmq

[18] KPK. (2017, 8 Desember). Mengenal Pengaduan Masyarakat. Diakses 21 Desember 2018 dari https://www.kpk.go.id/id/layanan-publik/pengaduan-masyarakat/mengenal-pengaduan-masyarakat

[19] KPK. (2017, 8 Desember). Mengenal LHKPN. Diakses 21 Desember 2018 dari https://www.kpk.go.id/id/layanan-publik/laporan-harta-kekayaan-penyelenggaraan-negara/me ngenal-Ihkpn

[20] KPK. (2018, 22 Februari). Indeks Persepsi Korupsi 2017, Skor Indonesia di Angka 37. Diakses 21 Desember 2018 dari https://www.kpk.go.id/id/berita/berita-kpk/229-ind e k s - p e r s e p si-korupsi-2017-skor-indonesia-di-angka-37 KPK. (2019, 30 Juni). Statistik Pengaduan

[21] Masyarakat Tahun Berjalan. Diakses 23 September 2019 dari https://www.kpk.go.id/id/statistik/pengaduan-masyarakat Kartika, W., Thaariq, R., Ningrum, D., \& Ramdlaningrum, H. (2019, Maret). Menguak Aliran Keuangan Gelap di Enam Komoditas Ekspor Unggulan Indonesia. Perkumpulan Prakarsa. Diakses 20 Juli 2019 dari http://theprakarsa.org/wp-content/up| o a d s/ $2019 / 04 / \mathrm{P}$ o l i cy-Brief-12-Menyoroti-Aliran-Keuangan-Ge lap-Di-Enam-Komoditas-Unggulan-EskporIndonesia.pdf

[22] Mohammad, Y. (2016, 5 April). Kerugian negara akibat korupsi di Indonesia Rp203,9 triliun. Diakses 21 Desember 2018 dari https://beritagar.id/artikel/berita/kerug i a n - n e g a r a - a ki b a t - k o rupsi-di-indonesia-rp2039-triliun

[23] Saputri, D. (2018, 19 Februari). ICW : Kerugian Negara Akibat Korupsi Meningkat. Republika.co.id. Diakses 20 Desember 2018 dari https://www.republika.co.id/berita/na$\mathrm{s}$ i $0 \mathrm{n}$ a $/$ / $\mathrm{h}$ u kum/18/02/19/p4e90f382-icw-kerugian-ne gara-akibat-korupsi-meningkat
[24] Transparency International. (2019, 29 Januari). Corruption Perception Index 2018. Jakarta: Transparency International. Diakses 8 September 2019 dari https://ti.or.id/corruption-perception-index-2018/ 